\title{
Effect of Working Capital Management on the Profitability of Steel Companies on Vietnam Stock Exchanges
}

\author{
Kien Xuan PHAM${ }^{1}$, Quang Ngọc NGUYEN², Cong Van NGUYEN ${ }^{3}$ \\ Received: August 01, 2020 Revised: September 06, 2020 Accepted: September 10, 2020
}

\begin{abstract}
This study examines the influence of working capital management (WCM) factors on the profitability of steel companies listed on the Stock Exchange of Vietnam. Data was collected from audited financial statements of companies for a period of 10 years, from 2010 to 2019 . The number of samples eligible for research is 20 out of 26 companies, which is equivalent to $76.9 \%$. With the help of dedicated software Stata version 14, the impact determination of WCM (through 8 independent variables: DIO, DPO, DSO, CCC, SIZ, CR, LEV, GRO) to the firm's profitability (through the dependent variable) is performed through multivariate regression models. Research results from companies in the steel industry in Vietnam during this period indicate that WCM has a strong impact on the profitability of businesses. Among 8 factors affecting the profitability of steel enterprises, factors DPO, DIO, DSO, CR, SIZ, GRO have a positive impact, boosting profitability; 2 factors CCC and LEV have a negative impact on profitability; in which, the effect of CCC is negligible. This conclusion is almost in contrast to many previously published studies due to the specifics of the industry as well as the different stages of economic development associated with the economic management policies of the State.
\end{abstract}

Keywords: Cash Conversion Cycle, Days Inventory Outstanding, Days Payable Outstanding, Days Sales Outstanding, Working Capital Management

JEL Classification Code: D22, G30, L25

\section{Introduction}

Working capital or net working capital is the difference between current assets and current liabilities of a company, or it is calculated by subtracting current assets from current liabilities. This relationship reflects the company's ability to pay short-term liabilities with short-term assets. Using and managing working capital has many impacts on the business performance of any business in both short-term

${ }^{1}$ First Author. School of Accounting and Auditing, The National Economics University (NEU). Email: kienpx.neu@gmail.com

${ }^{2}$ Associate Professor, School of Accounting and Auditing, The National Economics University (NEU). Email: nnq1966@gmail.com ${ }^{3}$ Corresponding Author. Professor, Industrial University of Ho Chi Minh City (IUH), Vietnam [Postal Address: 12 Nguyen Van Bao Street, Ward 4, Go Vap District, Ho Chi Minh City, 727900, Vietnam] Email: anhcongtuan@gmail.com

(c) Copyright: The Author(s)

This is an Open Access article distributed under the terms of the Creative Commons Attribution Non-Commercial License (https://creativecommons.org/licenses/by-nc/4.0/) which permits unrestricted non-commercial use, distribution, and reproduction in any medium, provided the original work is properly cited. and long-term, from paying employees and suppliers to planning sustainable growth (Soukhakian \& Khodakarami, 2019). In other words, working capital can be considered as a financial source for a company to pay its current or shortterm obligations. Therefore, working capital is not only a good ratio of a company's current financial position but also a measure of its overall performance.

Since working capital is so important to business operations, managers try to use working capital effectively. From there, arose the concept of working capital management (WCM). WCM forecasts short-term and improves processes, starting with purchasing raw materials and paying suppliers and ending with receivables from customers (Soukhakian \& Khodakarami, 2019). This is also the cash conversion cycle - CCC (Richards \& Laughlin, 1980; Aregbeyen, 2013; Yasir, Majid, \& Yousaf, 2014; Majanga, 2015; Chang, 2018). CCC is a tool that measures the time (in days) for a business to convert its investments in inventory and other resources into cash flows from sales. This is the amount of time it takes a business to sell its inventory (Days Inventory Outstanding - DIO), collect debts receivable from buyers (Days Sales Outstanding - DSO) and pay suppliers bills (Days Payable 
Outstanding - DPO) without penalty. In other words, CCC deals with money in and out of a company. DIO says how many days it takes a business to sell all its inventory. The DSO indicates the number of days it will take for the business to recover all the sale proceeds for the period. The DPO reflects the time it takes a company to pay suppliers off their bills without penalty. The purpose of working capital management is for managers to find all appropriate measures to minimize DIO and DSO and prolong DPO as much as possible.

There are many ways that a business can use to improve profitability and good management and WCM is one of the most effective ways. Therefore, there have been many studies on the relationship between WCM and profitability which have been carried out in many countries with many different fields which gave different results. These studies mainly use CCC and the three main elements of CCC (DIO, DSO and DPO) as the WCM measure. Most published studies often look at a wide range, including companies or listed companies of a country, and rarely have a study going into a particular industry or field.

Vietnam's steel industry is one of the key economic sectors of the country. In 2018, Vietnam's production output reached 14.1 million tons of crude steel, ranking 17th among the 20 largest steel producing countries in the world (Thanh, 2019). However, in general, steel enterprises in Vietnam have a small, fragmented and unsustainable production scale; production structure is narrow and monotonous; there is no technology investment condition; production capacity and product quality are low; labor productivity is not high. In terms of the form of payment, deferred payment is the method commonly applied in the Steel industry because steel products are mainly used for the construction industry. Only when the construction contractors complete the construction volume under the contract and collect the money, the steel enterprises can recover the money. Therefore, the time to recover the money sold is often prolonged, especially for projects with a large budget and using state budget. Around this time, the Government is promoting many construction activities and public investment to promote the country's economic development (Vietnam Steel Association, 2020). These features make WCM in the Vietnam Steel industry even more important and attract the attention of managers as well as create research demands on WCM for scientists.

\section{Literature Review}

Improving profits and honoring corporate values is always the concern of managers. Therefore, the consideration of the factors affecting profitability to propose, recommend and find effective and suitable solutions to improve profitability has been mentioned in many research. It is easy to find studies on factors that directly affect profitability such as financial leverage, solvency, liquidity, firm size, capital structure and working capital management (Chamberlain, 1962; DeAngelo \& Masulis, 1980; Bradley, Jarrell, \& Kim, 1984; Capon, Farley, \& Hoenig, 1990; Miao, 2005; Huang \& Song, 2006; Aburime, 2009; Anbar \& Alper, 2011; Fareed, Ali, Shahzad, Nazir, \& Ullah, 2016; Muhammad, Rehman, \& Waqas, 2016; Szymańska, 2017; Grau, \& Reig, 2018; Blažková, 2018; Yüksel, Mukhtarov, Mammadov, \& Özsarı, 2018; Qayyum \& Noreen, 2019; Vu, Do, Dang, \& Nguyen, 2019; Zheng, Liu, \& Huang, 2019; Nguyen \& Nguyen, 2020) or external factors influencing profitability such as market concentration, industry growth, import growth, GDP growth, inflation, and profitability. yield and profit on financial markets (Bei \& Wijewardana, 2012; Pattitoni, Petracci \& Spisni, 2014; Çelik, Bilen, \& Bilen, 2016; Jędrzejczak-Gas, 2017; Grau \& Reig, 2018; Soukhakian \& Khodakarami, 2019).

Regarding the relationship between working capital management and corporate profitability, although there are quite a few studies that have been published, the results of this relationship are still controversial. Most studies find that the opposite relationship between WCM and profitability or the volatility (increase, decrease) of CCC significantly affects the profitability of a company (Shin and Soenen, 1998; Song, Liu, \& Chen, 2012; Vahid, Elham, Mohsen, \& Mohammadreza, 2012; Aregbeyen, 2013; Tran, 2015; Lima, Martins, \& Brandão, 2015; Jamalinesari \& Soheili, 2015; Kasiran, Mohamad, \& Chin, 2016; Le, Ho, Le, \& Le, 2017; Botoc \& Anton, 2017; Ndumia \& Omagwa, 2019; Oladipupo, Adekanbi, \& Oluwadare, 2019; Yusuf, 2019; Gołaś, 2020).

Shin and Soenen (1998) studied at 58,985 firms over the period 1975-1994 and concluded that there is a significant relationship between the length of a firm's net trade cycle (NTC) and its profitability. They used NTC instead of CCC to measure WCM, because NTC is basically equal to the $\mathrm{CCC}$ where all its three components were expressed as a percentage of sales. In other words, it has a strong negative relationship between CCC and the profitability of a company. It means that the longer the NTC of a firm, the riskier it is for its profitability.

Deloof (2003) took his research on a survey of 1,009 big Belgian non- financial firms during the period of $1992-1996$ and found a substantial negative link between gross operating income and the number of days of accounts receivable, accounts payables and inventory. It means that, in order to raise the profitability of a firm, its manager should reduce the number of days accounts receivable, accounts payables and inventory while less profitable firms wait longer to pay their bills. In other words, this study concluded that there is a strong negative link between CCC and the profitability of the firm. Mansoori and Muhammad's study (2012) of 92 industrial companies in Singapore in the period 2004-2011 or study by Lazaridis and Tryfonidis (2006) of 131 companies 
listed on the Athens Stock Exchange between 2001-2004 also showed similar results.

Alipour (2011) executed a survey of 1,063 companies listed at the Tehran Stock Exchange during the period 2001 - 2006 and found a strong reverse link between CCC and profitability of these firms. In which, two component of $\mathrm{CCC}$ including accounts payables and inventory expressed a significant negative relationship with profitability; while accounts payables and profitability showed a direct strong relation. This research suggested managers should reduce accounts payables and inventory in order to raise firm's profitability.

Napompech (2012) when performing regression analysis on samples of 255 companies listed on the Stock Exchange of Thailand from 2007 to 2009 found an inverse relationship between operating gross profit and inventory conversion time and receivable debt collection. She suggested that managers can increase the profitability of a firm by reducing the $\mathrm{CCC}$, inventory conversion period and receivable collection period. This study also reminded that these surveyed companies cannot raise their profitability by deferring payments to their suppliers. Through considering the impact of factors reflected on the working capital on engineering product market competition performance, Song, Liu, and Chen (2012) found that the engineering working capital turnover ability, inventory turnover, liquid assets turnover, and receivables turnover have a positive impact on market competition performance. The study also found that the cash conversion cycle and the liquidity of working capital have a negative impact on competitive activities in the market.

Vural, Sökmen, and Çetenak (2012) studied 75 listed manufacturing firms on Istanbul Stock Exchange for the 2002 - 2009 period and concluded that the CCC and accounts payables are negatively related to profitability of a firm. It means that managers of a company can raise its profitability by reducing the collection period of accounts payables and CCC. At the same time, this work did not find any link between the number of day inventory, accounts payables and profitability.

Studying the effect of working capital management on the performance of companies listed on the Tehran Stock Exchange (TSE), Vahid, Elham, Mohsen, and Mohammadreza (2012) found the factors of the Average Collection Period, Inventory Turnover, Average Payout, Cash Conversion Cycle, and Net Trade profitability have a negative impact on profitability. This research also shows that the cash conversion cycle factor, although negatively related to profitability, is negligible. Gul et al. (2013) surveyed the impact of WCM on the profitability of 55 small and medium enterprises in Pakistan from 2006 - 2012 and found a positive relation between accounts payables and profitability; while there is a reverse link between accounts payables, inventory and $\mathrm{CCC}$ with increased profitability.
The study of Aregbeyen (2013) on the effectiveness of working capital management on the profitability of 48 large manufacturing firms on the Nigerian Stock Exchange (NSE) between 1993 and 2005 shows that WCM significantly reduces the profitability. The article concludes that improving WCM efficiency is essential and recommends that Nigerian manufacturing companies shorten the Average Collection Period, Average Payment Period, Inventory Turnover in Days and Cash Conversion Cycle. Studying the impact of working capital management on the profitability of SMEs in the Eurozone, Lima, Martins, and Brandão (2015) found such factors as average collection period, average payment period, average inventory period, cash conversion cycles are negatively associated with profitability. In examining the relationship between WCM and the performance of Sri Lankan listed manufacturing companies between 2011 and 2016, Vijayakumaran (2017) found that when working capital was low, the relationship was positive, conversely, when the level of working capital is high, the relationship is reversed. Deriving from this, the researchers recommend that the optimal working capital for businesses is to balance the costs and benefits of maintaining working capital and thereby maximize their performance.

For the purpose of examining the relationship between working capital management and firm profitability, using table data set on high-growth firms from Central, Eastern and Southeast Europe from 2006 to 2015, Botoc and Anton (2017) found an inverse U-shaped relationship between working capital level and firm's profitability. From there, they point out the importance of short-term financial decisions in enhancing high-growth firms' profits. Nobanee (2017) when looking at the relationship between working capital performance and profitability of construction firms listed in the United Arab Emirates found a negative relationship between the cycle of net trade and the profits of the construction firms over a period of crisis. The study results also show a positive and important relationship between the net trade cycle and the profitability of UAE construction companies during the non-crisis period.

Vijayakumaran and Vijayakumaran (2017), while studying Sri Lanka's listed manufacturing firms from 2011 to 2016, found that when working capital is low, the relationship between WCM and profitability is positive. On the contrary, when the level of working capital is high, this relationship is reversed. From there, the researchers recommend the optimal working capital for businesses to balance the costs and benefits of maintaining working capital and thereby maximizing operational efficiency. Oladipupo, Adekanbi and Oluwadare (2019) found that in companies listed on the Nigerian Stock Exchange, cash collection and spending have negative effects; the current ratio of payment and inventory period both have a positive impact on the rate of return of assets. From there, they recommend that while maintaining 
a shorter collection, they do not extend the payment time for creditors to enjoy a cash discount (if any) and businesses should be proactive in managing the principle. materials to avoid idle resources that could negatively impact their financial performance.

Soukhakian and Khodakarami (2019) when studying the relationship between working capital management and efficiency as well as the regulatory role of macroeconomic factors (inflation and GDP) in Iran's listed manufacturing firms, has found that the cash conversion cycle is negatively related to an asset's rate of return (ROA). Macroeconomic variables are positively and significantly related to ROA, but do not adjust the relationship between working capital management and business performance.

\section{Research Data and Models}

\subsection{Research Data}

The research data of the article are collected directly and is based on the audited financial statements of joint-stock companies in the steel industry officially published on the Vietnam Stock Exchange for a period of 10 years, from 2010 to 2019. As of March 31, 2020, on the Vietnamese stock exchange, there are a total of 26 listed companies in the steel industry; including 9 companies on the HOSE (Ho Chi Minh Stock Exchange, 2020); HNX has 4 companies (Hanoi Stock Exchange, 2018) and UPCOM has 13 companies (Cafef, 2020; cophieu68.vn, 2020; VietstockFinance, 2020). Some companies are excluded from the sample because they entered the stock market after 2010 or because their few years of financial statements have not been audited. As a result, 20 companies met the conditions for sampling with 200 observations, accounting for $76.9 \%$.

\subsection{Research Models}

So as to measure the profitability of steel companies on Vietnam Stock Exchange, this study uses ratio the Return On Assets (ROA) as the dependent variable, reflecting the profitability of assets and eight independent variables, including:

- DSO (Days Sales Outstanding): reflecting the collection policy.

- DIO (Days Inventory Outstanding): reflecting the inventory policy.

- DPO (Days Payable Outstanding): reflecting the payment policy.

- CCC (Cash Conversion Cycle): reflecting the WCM.

- SIZ (Size): reflecting the firm's size.

- LEV (Financial Leverage): reflecting the financial structure of the company.

- CR (Current Ratio): reflecting the current payment ability of the company.
- GRO (Growth): reflecting the growth speed of the company. All of these variables are described concretely in Table 1 below.

Regression model was built on the basis of using tabular data to evaluate the impact of 8 different factors (including DSO, DIO, DPO, CCC, SIZ, LEV, CR, GRO) on fertility profit (measured by ROA) of 20 steel companies listed on the Vietnam stock market from 2010 to 2019. The regression model is set up as follows:

$$
\begin{aligned}
\text { Model 1: ROA }= & \beta_{0}+\beta_{1}{ }^{*} \mathrm{DSO}+\beta_{2}{ }^{*} \mathrm{SIZ}+\beta_{3}{ }^{*} \mathrm{LEV}+ \\
& \beta_{4}{ }^{*} \mathrm{GRO}+\beta_{5}{ }^{*} \mathrm{CR}+\varepsilon \\
\text { Model 2: ROA }= & \beta_{0}+\beta_{1}{ }^{*} \mathrm{DIO}+\beta_{2}{ }^{*} \mathrm{SIZ}+\beta_{3}{ }^{*} \mathrm{LEV}+ \\
& \beta_{4}{ }^{*} \mathrm{GRO}+\beta_{5}{ }^{*} \mathrm{CR}+\varepsilon \\
\text { Model 3: ROA }= & \beta_{0}+\beta_{1}{ }^{*} \mathrm{DPO}+\beta_{2}{ }^{*} \mathrm{SIZ}+\beta_{3}{ }^{*} \mathrm{LEV}+ \\
& \beta_{4}{ }^{*} \mathrm{GRO}+\beta_{5}{ }^{*} \mathrm{CR}+\varepsilon \\
\text { Model 4: ROA }= & \beta_{0}+\beta_{1}{ }^{*} \mathrm{CCC}+\beta_{2}{ }^{*} \mathrm{SIZ}+\beta_{3}{ }^{*} \mathrm{LEV}+ \\
& \beta_{4}{ }^{*} \mathrm{GRO}+\beta_{5}{ }^{*} \mathrm{CR}+\varepsilon
\end{aligned}
$$

\begin{tabular}{|c|c|c|c|}
\hline Variable & \multicolumn{2}{|l|}{ Formula } & $\begin{array}{l}\text { Expected } \\
\text { Sign }\end{array}$ \\
\hline \multicolumn{4}{|c|}{ Dependent variable } \\
\hline \multirow{2}{*}{$\mathrm{ROA}=$} & Net Income & & \\
\hline & Average Total Assets & & \\
\hline \multicolumn{4}{|c|}{ Independent variable } \\
\hline \multirow[t]{2}{*}{$\mathrm{DSO}=$} & $\begin{array}{l}\text { Average Account } \\
\text { Receivables }\end{array}$ & \multirow[t]{2}{*}{ x 365} & - \\
\hline & Net Sales & & \\
\hline \multirow{2}{*}{$\mathrm{DIO}=$} & Average Inventory & \multirow{2}{*}{$x 365$} & - \\
\hline & Cost of Goods Sold & & \\
\hline \multirow{2}{*}{$\mathrm{DPO}=$} & Average Account Payables & \multirow{2}{*}{$x 365$} & - \\
\hline & Cost of Goods Sold & & \\
\hline $\mathrm{CCC}=$ & DSO + DIO - DPO & & - \\
\hline $\mathrm{SIZ}=$ & $\begin{array}{l}\text { Natural logarithm of Net } \\
\text { Sales }\end{array}$ & & + \\
\hline \multirow[b]{2}{*}{ LEV = } & Total Debts & & \\
\hline & $\begin{array}{l}\text { Total owners' equity \& } \\
\text { liabilities }\end{array}$ & & - \\
\hline \multirow{2}{*}{$\mathrm{CR}=$} & Current Assets & & + \\
\hline & Current Debt & & \\
\hline \multirow{2}{*}{$\mathrm{GRO}=$} & $\left(\right.$ Net Sales $_{\mathrm{i}}-$ Net Sales $\left._{\mathrm{i}-1}\right)$ & & + \\
\hline & Net Sales ${ }_{i-1}$ & & \\
\hline
\end{tabular}

where: $\beta_{0}, \beta_{1}, \beta_{2}, \beta_{3}, \beta_{4}$, and $\beta_{5}$ are correlation coefficients. $\varepsilon$ : is error.

Table 1: Summary of variables in the model 


\section{Results and Discussion}

\subsection{Descriptive Statistics}

Descriptive statistics of all 9 collected variables are summarized in Table 2. Table 2 shows that the mean value of the profits of 20 companies is $3.39 \%$ with a standard deviation of $6.18 \%$. The maximum value for ROA is $25.45 \%$ while the minimum is $-25.57 \%$. On an average, these firms took about 103 days to convert their inventory into sales. However, the quickest firm took approximately 6 days to clear its inventory; while this figure of the slowest firm was nearly three years (1,002 days). These companies granted the credit period at nearly two months (58 days) while they paid their suppliers after 160 days (or later five-month) on an average. Overall CCC ranged only two days (see Table 2).

\subsection{Correlation Analysis}

From Table 3, it can be seen that four independent variables including DSO, DIO, DPO and LEV have a negative relationship with profitability. This is consistent with most researches by Shin and Soenen (1998), Deloof (2003), Lazaridis and Tryfonidis (2006), Napompech (2012), Mansoori and Muhamad (2012), Tran (2015), Le, Ho, Le, and Le (2017), etc. The remaining independent variables have a positive relationship with profitability (see Table 3 ).

\subsection{Multiple Regression Analysis}

So as to find the link between CCC and each of its components on profitability, after moving data from excel and coding them in Stata 14, we run regressions for all four above mentioned models by both Fixed Effects Model (FEM) and Random Effects Model (REM). Then we compared these models by Hausman command. With P-value or $\alpha$ lower than $0.05 \%$, we chose FEM (and vice versa) as well as checked its defects comprising Multi-collinearity, Heteroskedasticity and Autocorrelation. After that, we correct them and we got the below concrete results.

$$
\begin{aligned}
R O A= & -0.176108+0.000078 * D S O+0.017386 * S I Z \\
& -0.172742 * L E V+0.008918 * G R O \\
& +0.045 * C R .
\end{aligned}
$$

From Table 4, DSO has a positive relationship with profitability and its correlation coefficient is 0.000078 and P-value of 0.015 ; or this relationship has a statistical significance at $5 \%$ level. It means that, the higher of DSO, the better for the profitability of these companies. This result is opposite to many studies by Shin and Soenen (1998), Deloof (2003), Lazaridis and Tryfonidis (2006), Gill, Biger, and Mathur (2010), Napompech (2012), Mansoori and Muhamad (2012), Gul et al. (2013), Tran (2015), Le, Ho, Le,

\begin{tabular}{|c|c|c|c|c|c|}
\hline \multicolumn{6}{|l|}{ sum } \\
\hline Variable | & Obs & Mean & Std. Dev. & Min & Max \\
\hline \multicolumn{6}{|c|}{ - } \\
\hline Name | & 0 & & & & \\
\hline Year | & 200 & 2014.5 & 2.879489 & 2010 & 2019 \\
\hline ROA & 200 & .0339356 & .0618349 & -.2556662 & .254517 \\
\hline DSO | & 200 & 58.94595 & 96.16931 & 8.277415 & 890.2455 \\
\hline DIO | & 200 & 103.1946 & 118.5696 & 5.717406 & 1002.014 \\
\hline \multicolumn{6}{|c|}{ 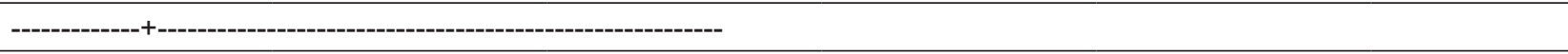 } \\
\hline DSO | & 200 & 160.126 & 188.4197 & 21.94517 & 1762.583 \\
\hline $\mathrm{CCC} \mid$ & 200 & 2.014546 & 49.75887 & -146.3578 & 353.7723 \\
\hline SIZ I & 200 & 14.70584 & 1.459341 & 9.966556 & 17.96904 \\
\hline LEV | & 200 & .638707 & .1309642 & .2483525 & .9310266 \\
\hline GRO | & 200 & .1941348 & .6861765 & -.9862477 & 5.510258 \\
\hline \multicolumn{6}{|c|}{ 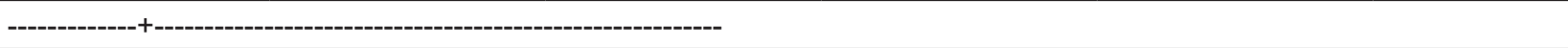 } \\
\hline CR I & 200 & 1.285862 & .4415298 & .5647412 & 3.71911 \\
\hline NAME | & 200 & 10.5 & 5.780751 & 1 & 20 \\
\hline
\end{tabular}
and Le (2017), etc. (see Table 4).

Table 2: Descriptive statistics 
Table 3: Correlation coefficients between variables

\begin{tabular}{|c|c|c|c|c|c|c|c|c|c|}
\hline \multicolumn{10}{|c|}{. corr ROA DSO DIO DPO SIZ LEV GRO CR } \\
\hline \multicolumn{10}{|c|}{$(o b s=200)$} \\
\hline & I & ROA & DSO & Dlo & DPO & SIZ & LEV & GRO & $\mathrm{CR}$ \\
\hline \multicolumn{10}{|c|}{ 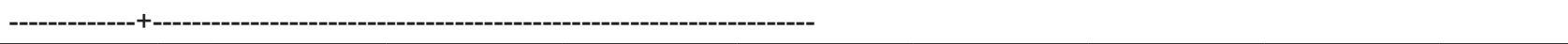 } \\
\hline ROA & 1 & 1.0000 & & & & & & & \\
\hline DSO & I & -0.2255 & 1.0000 & & & & & & \\
\hline DIO & I & -0.2037 & 0.7688 & 1.0000 & & & & & \\
\hline DPO & I & -0.2554 & 0.9051 & 0.9190 & 1.0000 & & & & \\
\hline SIZ & I & 0.2556 & -0.4864 & -0.4206 & -0.4020 & 1.0000 & & & \\
\hline LEV & | & -0.4759 & 0.2157 & 0.1809 & 0.3185 & 0.1202 & 1.0000 & & \\
\hline GRO & I & 0.1759 & -0.1021 & -0.1464 & -0.1461 & 0.0492 & 0.0160 & 1.0000 & \\
\hline CR & 1 & 0.3364 & -0.0000 & 0.0058 & -0.1625 & -0.3794 & -0.7567 & 0.0267 & 1.0000 \\
\hline
\end{tabular}

Table 4: Regression result of Model 1

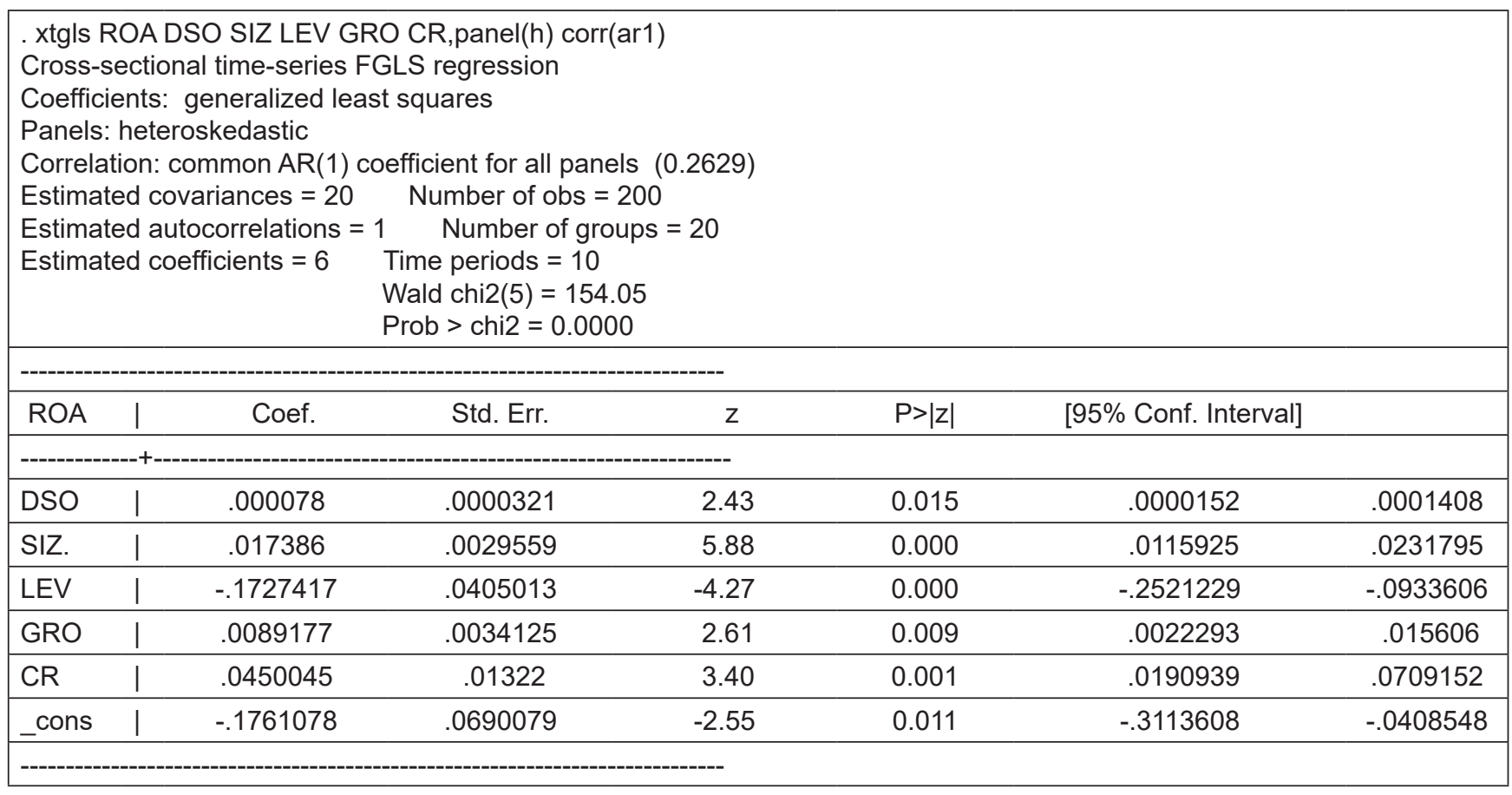

Similarly, the regression results of model $2\left(\mathrm{ROA}=\beta_{0}+\right.$ $\left.\beta_{1}{ }^{*} \mathrm{DIO}+\beta_{2}{ }^{*} \mathrm{SIZ}+\beta_{3}{ }^{*} \mathrm{LEV}+\beta_{4}{ }^{*} \mathrm{GRO}+\beta_{5}{ }^{*} \mathrm{CR}+\varepsilon\right)$ show that DIO also has a positive relationship with profitability and its correlation coefficient is 0.0000651 and P-value of 0.023 ; or this relationship has a statistical significance at $5 \%$ level. It means that, the longer of INV, the better the profitability of the steel companies. This result contrasts to studies by Deloof (2003), Napompech (2012), Alipour
(2011), Mansoori and Muhamad (2012), Gul et al. (2013), Tran (2015), Le, Ho, Le, and Le (2017).

Research by Lazaridis and Tryfonidis (2006) also revealed this negative association, while Gill, Biger, and Mathur (2010) detected a positive tie between DIO and profitability although this relation is also insignificant statistically.

$$
\begin{aligned}
R O A= & -0.183293+0.000065 * D I O+0.017422 * S I Z \\
& -0.168527 * L E V+0.009274 * G R O+0.0465 * C R .
\end{aligned}
$$




$$
\begin{aligned}
R O A= & -0.193043+0.000046 * D P O+0.017823 * S I Z \\
& -0.171292 * L E V+0.009249 * G R O+0.05 * C R .
\end{aligned}
$$

From Table 5, DPO also has a positive relationship with profitability and its correlation coefficient is 0.0000463 and P-value of 0.006; or this relationship has a statistical significance at $5 \%$ level. This suggests that the longer a company extends its supplier billing period, the more opportunities it has to increase its working capital; from there, the profitability increases. In other words, in order to increase profits, companies need to extend the payment time of the goods within their allowances so that they don't get penalized for overdue payments (see Table 5).

This result is the same with studies by Lazaridis and Tryfonidis (2006), Alipour (2011) and Gul et al. (2013). However, it differs from the findings by Deloof (2003), Mansoori and Muhamad (2012), Tran (2015), Le, Ho, Le, and Le (2017). This result contradicts the conclusions of Gill, Biger, and Mathur (2010), Napompech (2012) and Vural, Sökmen, and Çetenak (2012) when their studies concluded that there was no statistically significant relationship between DPO and profitability.

For regression model 4, while running the regression with CCC, because P-value or $\alpha$ value is $0.05 \%$ higher, we choose REM (instead of FEM). We then compare REM and Ordinary Least Square (OLS) and select OLS as well as check and fix its defects. Finally, we have the results.

$$
\begin{aligned}
R O A= & -0.114859-0.000119 * C C C+0.014578^{*} S I Z- \\
& 0.175014^{*} L E V+0.014336^{*} G R O+0.033^{*} C R .
\end{aligned}
$$

The regression results in Table 6 show that: With the statistical significance of $10 \%$ and the correlation coefficient of 0.0001085 , P-value of $0.387, \mathrm{CCC}$ has an inverse relationship with profitability. This result is similar to the most studies by Shin and Soenen (1998), Lazaridis and Tryfonidis (2006), Vural et al. (2012), Mansoori and Muhamad (2012), Gul et al. (2013), Tran (2015), Le, Ho, Le, and Le (2017), etc. This is in contrast to the research results of Gill, Biger, and Mathur (2010) when they found a positive relationship between CCC and profitability (see Table 6).

\section{Conclusions}

As an important operational tool, directly related to performance, WCM helps managers balance short-term assets and liabilities. The impact of WCM on profitability in this article relates to the Steel Industry companies listed on the Vietnamese stock market for the 10-year period from 2010 to 2019. From the research results, it is possible to find a significant difference in the effects of 8 different independent variables on profitability. Specifically, all three independent variables (DPO, DIO, and DSO) have a positive relationship with the profitability of the Steel Industry companies and all their P-value are smaller than 0.03 , or

Table 5: Regression result of Model 3

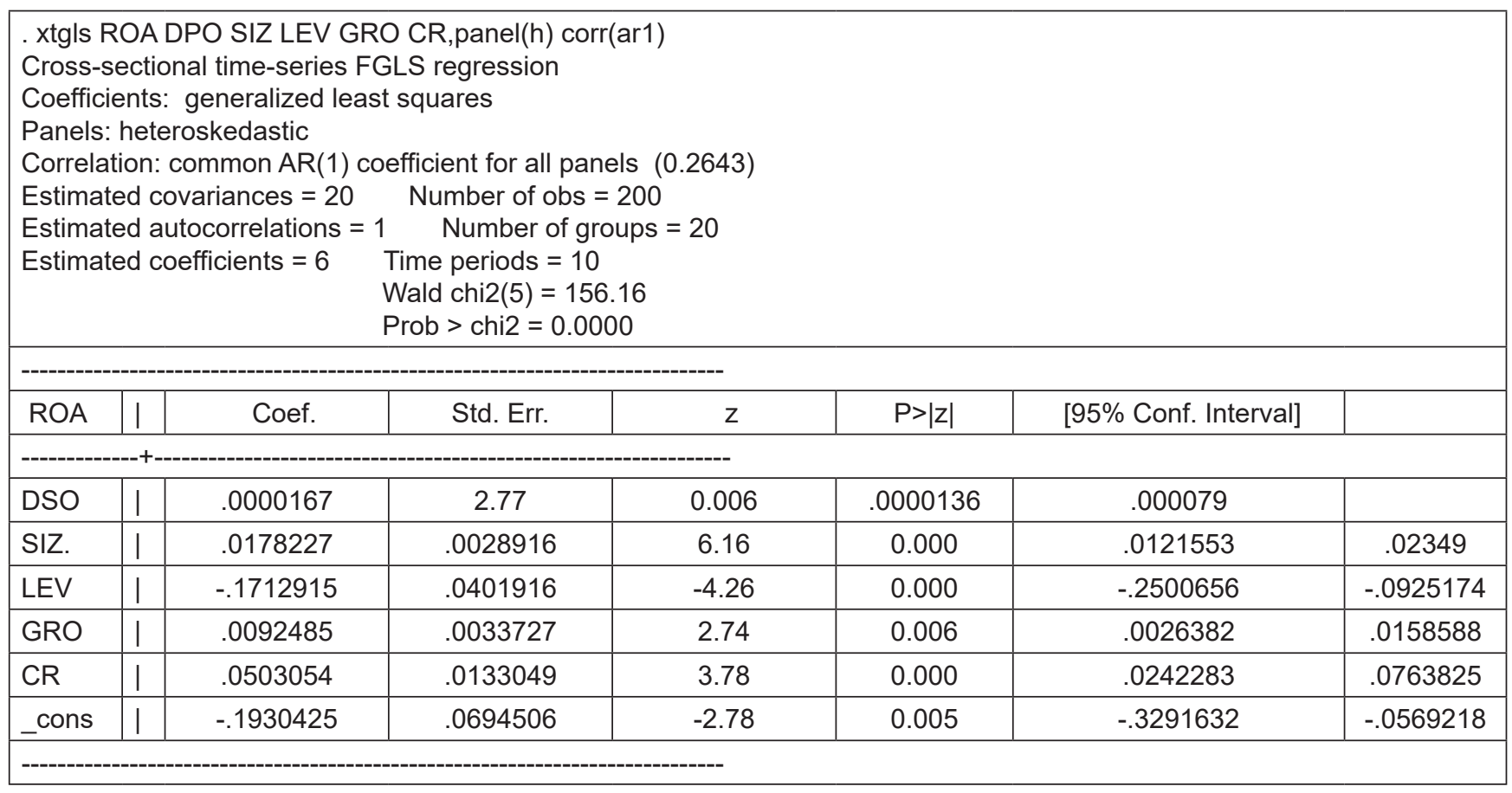


Table 6: Regression result of Model 4

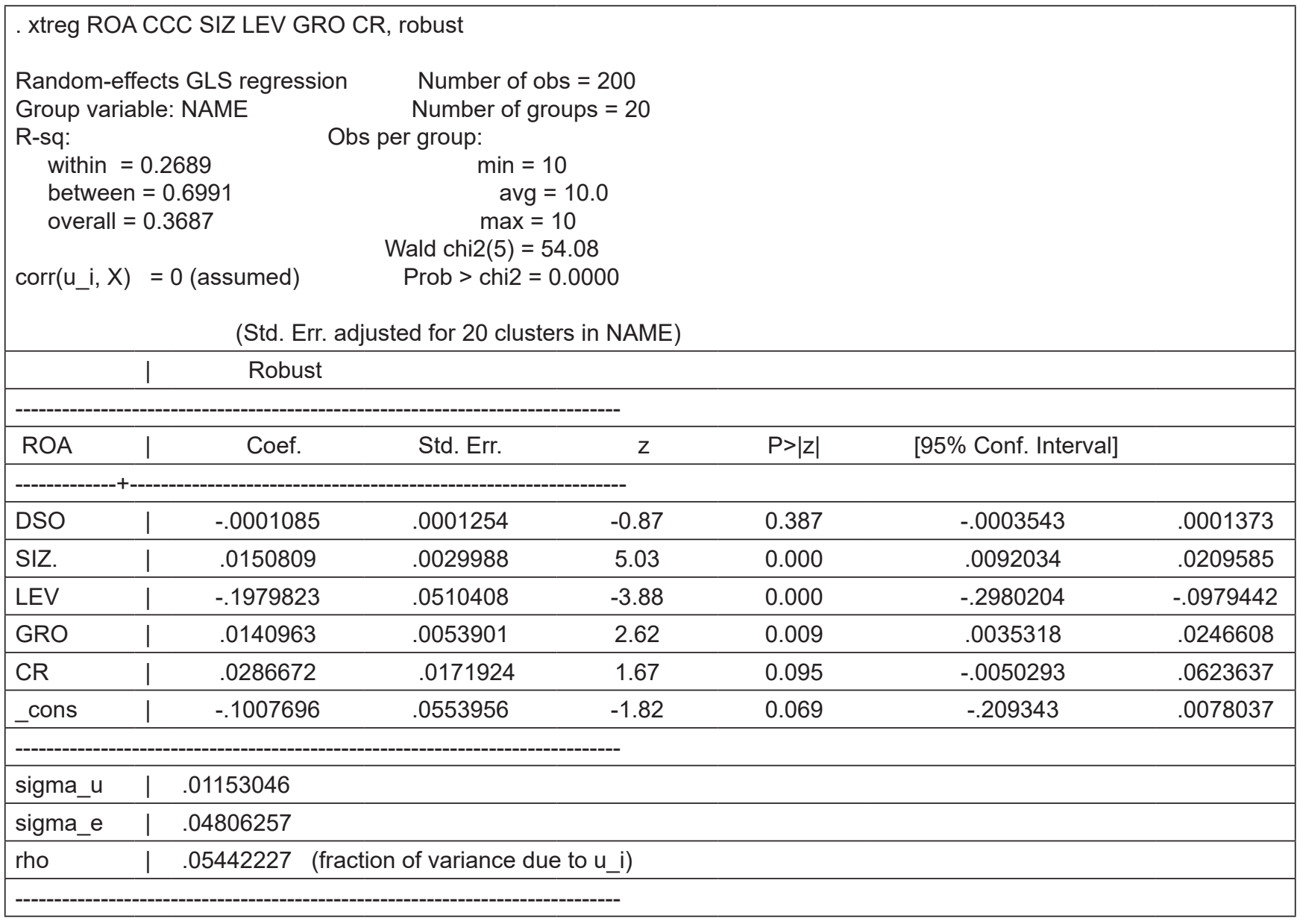

these links have a statistical significance at 5\% level. This means that, the longer number of days of DPO, DIO, and DSO, the better it is for the profitability of these companies. In contrast, $\mathrm{CCC}$ has a negative tie with profitability which means that a shorter CCC leads to better profitability; but it has no meaning in terms of statistical significance (more than $38 \%$ ). Besides, this study also finds the certain impact of a scale, a financial structure (that has a biggest coefficient, at least 0.16 ), a current payment ability, a growth speed of a company on its profitability.

The results of this study once again contributes to confirm the positive effect of WCM on the profitability of companies. The limitation of this paper is only to consider the impact of WCM on profitability through ROA, but not consider the impact of WCM on other profitability indicators (ROE, ROS, ROIC, ROCE). On the other hand, the research sample of the article is not extensive, only encapsulated in listed companies in the Steel Industry in Vietnam. Hopefully, in the future, these limitations will be taken care of in another in-depth, more extensive study.

\section{References}

Aburime, T. (2009). Determinants of Bank Profitability: Macroeconomic Evidence from Nigeri. International Economics and Finance Journal, 4(1-2), 69-91. https://doi. org/10.2139/ssrn.1231064. Retrieved from http://ssrn.com/ abstract $=1231064$

Alipour, M. (2011). Working Capital Management and Corporate Profitability: Evidence from Iran. World Applied Sciences Journal, 12(7), 1093-1099.

Anbar, A., \& Alper, D. (2011). Bank Specific and Macroeconomic Determinants of Commercial Bank Profitability: Empirical Evidence from Turkey. Business and Economics Research Journal, 2(2), 139-152. https://ssrn.com/abstract=1831345.

Aregbeyen, O. (2013). The effects of working capital management on the Profitability of Nigerian manufacturing firms. Journal of Business Economics and Management, 14(3), 520-534. doi:10. 3846/16111699.2011.651626.

Bei, Z., \& Wijewardana, W. P. (2012). Working capital policy practice: Evidence from Sri Lankan companies. Procedia - 
Social and Behavioral Sciences, 40, 695-700. doi:10.1016/j. sbspro.2012.03.251.

Blažková, I. (2018). Sectoral and Firm-Level Determinants of Profitability: A Multilevel Approach. International Journal of Entrepreneurial Knowledge, 6(2), 32-44. DOI: 10.2478/IJEK2018-0012.

Botoc, C., \& Anton, S. G. (2017). Is profitability driven by working capital management? Evidence for high-growth firms from emerging Europe. Journal of Business Economics and Management, 18(6), 1135-1155. doi:10.3846/16111699.2017. 1402362.

Bradley, M., Jarrell, G. A., \& Kim, H. A. (1984). On the Existence of an optimal capital structure: Theory and Evidence. The Journal of Finance, 39(3), 857-879. DOI: 10.2307/2327950.

Cafef. (2020, 4 20). List of listed companies in Vietnam. Retrieved from http://cafef.vn/doanh-nghiep.chn

Capon, N., Farley, J. U., \& Hoenig, S. (1990). Determinants of Financial Performance: A Meta-Analysis. Management Science, 36(10), 1137-1292. https://doi.org/10.1287/mnsc.36.10.1143.

Chamberlain, E. H. (1962). The Theory of Monopolistic Competition: A Re-orientation of the Theory of Value. Cambridge, MA: Harvard University Press.

Chang, C.-C. (2018). Cash conversion cycle and corporate performance: Global evidence. International Review of Economics \& Finance, 56, 568-581. https://doi.org/10.1016/j. iref.2017.12.014.

Çelik, R., Bilen, B., \& Bilen, O. (2016). The Impacts of Changes in Macro-Economic Data on Net Working Capital: The Case of Turkey's Industrial Sector. Procedia Economics and Finance, 38, 122-134. doi:10.1016/S2212-5671(16)30184-8.

cophieu68.vn. (2020). List of listed companies in Vietnam. Retrieved August 3, 2020, from https://www.cophieu68.vn/company_ financial.php?year $=2016 \&$ category $=\% 5$ Ethep\&lang $=$ en

DeAngelo, H., \& Masulis, R. (1980, 3). Optimal capital structure under corporate and personal taxation. Journal of Financial Economics, $\quad 8(1), \quad 3-29 . \quad \mathrm{https} / / /$ doi.org/10.1016/0304405X(80)90019-7.

Deloof, M. (2003). Does Working Capital Management Affect Profitability of Belgian Firms. Journal of Business Finance \& Accounting, 30(3-4), 573-588. DOI: 10.1111/1468-5957.00008.

Fareed, Z., Ali, Z., Shahzad, F., Nazir, M. I., \& Ullah, A. (2016). Determinants of Profitability: Evidence from Power and Energy Sector. Studia Universitatis Babes-Bolyai Oeconomica, 61(3), 59-78. DOI: https://doi.org/10.1515/subboec-2016-0005.

Gill, A., Biger, N., \& Mathur, N. (2010). The Relationship Between Working Capital Management And Profitability: Evidence From The United States. Business and Economics Journal, 10, 1-9. https://www.researchgate.net/publication/284875433.

Gołaś, Z. (2020). Impact of working capital management on business profitability: Evidence from the Polish dairy industry. Agricultural Economics - Czech, 66(6), 278-285. https://doi. org/10.17221/335/2019-AGRICECON.
Grau, A. J., \& Reig, A. (2018). Trade credit and determinants of profitability in Europe. The case of the agri-food industry. International Business Review, 27(5), 947-957. https://doi. org/10.1016/j.ibusrev.2018.02.005.

Gul, S., Khan, M. B., Rehman, S. U., Khan, M. T., Khan, M., \& Khan, W. (2013). Working Capital Management and Performance of SME Sector. European Journal of Business and Management, 5(1), 60-69.

Hanoi Stock Exchange. (2018). List of listed companies in Vietnam. Retrieved from https://www.hnx.vn/vi-vn/cophieu-etfs/chungkhoan-ny.html

Ho Chi Minh Stock Exchange. (2020). List of listed companies in Vietnam. Retrieved from https:/www.hsx.vn/Modules/Listed/ Web/Symbols?fid=18b12d5d2d554559bf10eeb90304ff2e

Huang, G., \& Song, F. M. (2006, 8 13). The determinants of capital structure: Evidence from China. China Economic Review, 17(1), 14-36. https://doi.org/10.1016/j.chieco.2005.02.007.

Jamalinesari, S., \& Soheili, H. (2015). The Relationship between the Efficiency of Working Capital Management Companies and Corporate Rule in Tehran Stock Exchange. Procedia Social and Behavioral Sciences, 205, 499-504. doi:10.1016/j. sbspro.2015.09.052.

Jędrzejczak-Gas, J. (2017). Net Working Capital Management Strategies in the Construction Enterprises Listed on the NewConnect Market. Procedia Engineering, 182, 306-313. doi:10.1016/j.proeng.2017.03.098.

Kasiran, F. W., Mohamad, N. A., \& Chin, O. (2016). Working Capital Management Efficiency: A Study on the Small Medium Enterprise in Malaysia. Procedia Economics and Finance, 35, 297-303. doi:10.1016/S2212-5671(16)00037-X.

Lazaridis, I., \& Tryfonidis, D. (2006). Relationship between Working Capital Management and Profitability of Listed Companies in the Athens Stock Exchange. Journal of Financial Management and Analysis, 19(1), 112-123. https://ssrn.com/ abstract $=931591$.

Le, T. D., Ho, N. V., Le, A. N., \& Le, M. Q. (2017). The Relationship between Working Capital Management and Profitability: Evidence in Vietnam. International Journal of Business and Management, 12(8), 175-181. doi:10.5539/ijbm.v12n8p175.

Lima, V., Martins, F. V., \& Brandão, E. (2015). The Management of Working Capital and Profitability of SMEs in the Euro Area. SSRN Journal, 1-48. http://dx.doi.org/10.2139/ssrn.2704622.

Majanga, B. B. (2015). Cash Conversion Cycle and Firm Profitability in Malawi Manufacturing Sector. Journal of Commerce \& Accounting Research, 4(3-4), 1-7.

Mansoori, E., \& Muhammad, D. (2012). The Effect of Working Capital Management on Firm's Profitability: Evidence from Singapore. Interdisciplinary Journal of Contemporary Research in Business, 4(5), 472-486. https://ssrn.com/abstract=2185840.

Miao, J. (2005). Optimal structure and industry dynamics. The Journal of Finance, 60(6), 2621-2659. https://www.jstor.org/ stable/3694799. 
Muhammad, H., Rehman, A. U., \& Waqas, M. (2016). The Relationship between Working Capital Management and Profitability: A Case Study of Tobacco Industry of Pakistan. Journal of Asian Finance, Economics and Business, 3(2), 13-20. doi: 10.13106/jafeb.2016.vol3.no2.13.

Napompech, K. (2012). Effects of Working Capital Management on the Profitability of Thai Listed Firms. International Journal of Trade Economics and Finance, 227-232. DOI: 10.7763/ IJTEF.2012.V3.205.

Ndumia, I. M., \& Omagwa, J. (2019). Working Capital Management and Profitability of Firms Listed Under Manufacturing and Allied Sector at the Nairobi Securities Exchange, Kenya. IOSR Journal of Economics and Finance, 10(6), 23-37. DOI: 10.9790/5933-1006032337.

Nguyen, L. T., \& Nguyen, C. V. (2020). The Determinants of Profitability in Listed Enterprises: A Study from Vietnamese Stock Exchange. Journal of Asian Finance, Economics and Business, 7(1), 47-58. doi:10.13106/jafeb.2020.vol7.no1.47.

Nobanee, H. (2017). Efficiency of Working Capital Management and Profitability of UAE Construction Companies: Size and Crisis Effects. SSRN Electronic Journal, 1-6. DOI: 10.2139/ ssrn.2971477.

Oladipupo, F. O., Adekanbi, J. A., \& Oluwadare, O. E. (2019). Working Capital Management and Firms' Profitability: Evidence from Quoted Firms on the Nigerian Stock Exchange. Intelligent Information Management, 11(3), 43-60. DOI: 10.4236/iim.2019.113005.

Pattitoni, P., Petracci, B., \& Spisni, M. (2014). Determinants of profitability in the EU-15 area. Journal applied finance and economy, 24(11), 763-775. https://doi.org/10.1080/09603107. 2014.904488.

Qayyum, N. U., \& Noreen, U. (2019). Impact of Capital Structure on Profitability: A Comparative Study of Islamic and Conventional Banks of Pakistan. Journal of Asian Finance, Economics and Business, 6(4), 65-74. doi:10.13106/jafeb.2019.vol6.no4.65.

Richards, V. D., \& Laughlin, E. J. (1980). A Cash Conversion Cycle Approach to Liquidity Analysis. Financial Management, 9(1), 32-38. DOI: $10.2307 / 3665310$.

Shin, H. H., \& Soenen, L. (1998). Efficiency of Working Capital Management and Corporate Profitability. Financial Practice \& Education, 8(2), 37-45.

Song, Z., Liu, D., \& Chen, S. (2012). A Decision Engineering Method to Identify the Competitive Effects of Working Capital: A Neural Network Model. Systems Engineering Procedia, 5, 326-333. doi:10.1016/j.sepro.2012.04.051.

Soukhakian, I., \& Khodakarami, M. (2019). Working capital management, firm performance and macroeconomic factors: Evidence from Iran. Cogent Business \& Management, 6, 1-24. https://doi.org/10.1080/23311975.2019.1684227.

Szymańska, E. J. (2017). The determinants of profitability of enterprises of meat industry in Poland. Acta Scientiarum Polonorum, Oeconomia, 16(3), 83-91. DOI: 10.22630/ ASPE.2017.16.3.36.
Thanh, L. (2019). Vietnam is among the top 20 largest steel producing countries in the world. Retrieved August 5, 2020, from https://ndh.vn/infographic/kim-loai/viet-nam-nam-trongtop-quoc-gia-san-xuat-thep-lon-nhat-the-gioi-1252660.html

Tran, H. V. (2015). Impact of working capital management on firm profitability: The case of listed manufacturing firms on Ho Chi Minh Stock Exchange. Asian Economic and Financial Review, 5(5), 779-789. DOI: 10.18488/journal. aefr/2015.5.5/102.5.779.789.

Vahid, T. K., Elham, G., Mohsen, A. K., \& Mohammadreza, E. (2012). Working capital management and corporate performance: Evidence from Iranian companies. Procedia Social and Behavioral Sciences, 62, 1313-1318. doi:10.1016/j. sbspro.2012.09.225.

Vietnam Steel Association. (2020). Vietnam steel market in July 2020 and the first 7 months of 2020. Retrieved August 15, 2020, from http://vsa.com.vn/tinh-hinh-thi-truong-thep-vietnam-thang-7-2020-va-7-thang-dau-nam-2020/

VietstockFinance. (2020). List off listed companies in Vietnam. Retrieved from https://finance.vietstock.vn/doanh-nghiep-a$\mathrm{z}$ ?page $=1$

Vijayakumaran, R., \& Vijayakumaran, S. (2017). Working Capital Management and Corporate Performance: Evidence from Sri Lankan Listed Manufacturing Firms. International Journal of Accounting and Financial Reporting, 7(2), 577-591. doi. org/10.5296/ijafr.v7i2.12453.

Vu, V. T., Do, N. H., Dang, H. N., \& Nguyen, T. N. (2019). Profitability and the Distance to Default: Evidence from Vietnam Securities Market. Journal of Asian Finance, Economics and Business, 6(4), 53-63. https://doi.org/10.13106/ jafeb.2019.vol6.no4.53.

Vural, G., Sökmen, A. G., \& Çetenak, E. H. (2012). Affects of Working Capital Management on Firm's Performance: Evidence from Turkey. International Journal of Economics and Financial Issues, 2(4), 488-495.

Yasir, M., Majid, A., \& Yousaf, Z. (2014). Cash Conversion Cycle and its Impact upon Firm Performance: An Evidence from Cement Industry of Pakistan. Global Business \& Management Research: An International Journal, 6(2), 139-149.

Yusuf, M. B. (2019). The impact of working capital management practice on firm profitability: An evidence from manufacturing firms in Istanbul Stock Exchange. The Journal of International Social Research, 12(62), 1645-1655.http://dx.doi.org/10.17719/ jisr.2019.3172.

Yüksel, S., Mukhtarov, S., Mammadov, E., \& Özsarı, M. (2018). Determinants of Profitability in the Banking Sector: An Analysis of Post-Soviet Countries. Economies, 6(3), 1-15. DOI: 10.3390 /economies6030041.

Zheng, S.-Y., Liu, M.-H., \& Huang, J.-D. (2019). The Influence of Community Structure on the Diffusion of Knowledge - A View Based on Market Segmentation. International Journal of Emerging Technologies in Learning, 14(8), 97-114. DOI: 10.3991/ijet.v14i08.10397. 